Article

\title{
High Rate of Oral Candida Detection in Dependent Japanese Older People
}

\author{
Mari Matsumura ${ }^{1}$, Hideo Shigeishi ${ }^{1, *}$, Cheng-Yih Su ${ }^{2}$, Rumi Nishimura ${ }^{3}$, Kouji Ohta ${ }^{1}$ and \\ Masaru Sugiyama ${ }^{1}$ \\ 1 Department of Public Oral Health, Program of Oral Health Sciences, Graduate School of Biomedical and \\ Health Sciences, Hiroshima University, Hiroshima 734-8553, Japan; m183935@hiroshima-u.ac.jp (M.M.); \\ otkouji@hiroshima-u.ac.jp (K.O.); masaru@hiroshima-u.ac.jp (M.S.) \\ 2 Department of Oral Health Management, Program of Oral Health Sciences, Graduate School of Biomedical \\ and Health Sciences, Hiroshima University, Hiroshima 734-8553, Japan; d181880@hiroshima-u.ac.jp \\ 3 Department of Oral Epidemiology, Program of Oral Health Sciences, Graduate School of Biomedical and \\ Health Sciences, Hiroshima University, Hiroshima 734-8553, Japan; r-nishimura@hiroshima-u.ac.jp \\ * Correspondence: shige@hiroshima-u.ac.jp; Tel.: +81-82-257-5945; Fax: +81-82-257-5945
}

Received: 24 January 2020; Accepted: 22 March 2020; Published: 24 March 2020

\begin{abstract}
The aim of this study was to clarify the association between oral Candida detection and the dependency status of older people. This study included 31 older people aged $\geq 70$ years who had a certified need for long-term care or support and received care in a local day care center; it also included 27 independent older patients aged $\geq 70$ years who visited Hiroshima University Hospital. Oral Candida was detected by a polymerase chain reaction using swab samples from the tongue surface. Oral moisture was significantly reduced in dependent older people, compared with independent older people $(p=0.003)$. There was a weak negative relationship between numbers of bacteria and levels of oral moisture (Spearman's rank correlation coefficient; $\mathrm{R}=-0.29, p=0.01$ ). Dependent older people exhibited a significantly higher rate of Candida albicans detection (35.5\%) compared with independent older people (11.1\%). Dependent older people also exhibited a higher rate of concurrent detection of both C. albicans and Candida glabrata (32.3\%) compared with independent older people $(11.1 \%)$, but this difference was not statistically significant. Thus, dependent older people may be more susceptible to oral C. albicans infection, compared with independent older people. Good oral hygiene is necessary to prevent oral Candida infection in dependent older people.
\end{abstract}

Keywords: Candida albicans; Candida glabrata; Candida tropicalis; dependent older people; oral moisture; denture

\section{Introduction}

The oral cavity contains diverse microbial communities, consisting of bacteria, fungi, and viruses. Recent research has shown that oral diseases (e.g., periodontitis) are associated with high serum $\mathrm{HbA1c}$ levels and low serum vitamin $C$ levels, suggesting an important relationship between oral health and general health condition [1,2]. Therefore, maintenance of good oral hygiene is vital for ensuring oral and general health at all stages of life. Notably, poor oral hygiene is associated with risks of aspiration pneumonia and oral candidiasis in older people [3,4]. Aspiration pneumonia occurs due to swallowing difficulties (i.e., dysphagia) and the aspiration of oral resident bacteria in older people. In addition, oral candidiasis is a common fungal infection in older people [5]. Oral candidiasis is caused by an impaired immune mechanism, medication use, xerostomia, and denture use in older people $[5,6]$. Common clinical features of chronic atrophic candidiasis (i.e., denture-related stomatitis due to the presence of Candida) are erythema and edema of the mucosa. The long-term use of dentures and poor oral hygiene 
presumably contributes to the risk of oral candidiasis by producing an environment ideal for growth of Candida. In addition, decline in activities of daily living may be associated with oral candidiasis due to poor oral health care in older people.

Thus far, the prevalence of oral Candida in older Japanese people has not been fully investigated. The aim of this study was to clarify the association between oral Candida detection and the dependency status of older people. Therefore, the present study investigated the rate of Candida detection in the oral cavity in dependent older people who had a certified need for long-term care or support, as well as in independent older people. In addition, the study investigated the relationship between the rate of oral Candida detection and clinical factors, such as medical history and oral health status.

\section{Materials and Methods}

\subsection{Participants}

This study included 31 dependent older people aged $\geq 70$ years (nine men, 22 women; mean age, 85.1 years) who had a certified need for long-term support or nursing care, from October 2018 to October 2019. Of the 31 older people, nine required long-term support and 22 required nursing care. These individuals typically lived at home and regularly received support and care at a local day care center in Hiroshima City. In addition, this study included 27 independent older patients aged $\geq 70$ years (six men, 21 women; mean age, 82.8 years) who visited Hiroshima University Hospital from March 2019 to December 2019. Of these 27 patients, none had a certified need for long-term support or nursing care. The study protocol was approved by the Ethical Committee of Hiroshima University, and all participants provided written informed consent.

\subsection{Oral Examination}

Oral samples were collected a few hours after participants had eaten breakfast, following tooth brushing. Therefore, most participants exhibited good oral hygiene before the oral examination and sample collection. Oral moisture was evaluated by an oral moisture-checking device (Moisture Checker Mucus ${ }^{\circledR}$, Scalar Corporation, Tokyo, Japan), as previously described [7]. This device can measure the percentage of water at the surface of the oral mucosa by means of measuring the dielectric constant. The sensor of the device, protected by a disposable polyethylene cover, was applied to the measurement site at a pressure of approximately $200 \mathrm{~g}$. The oral moisture level was measured at the tongue dorsum, with median values calculated from three independent measurements. A Bacterial Counter (Panasonic Healthcare Co., Ltd., Tokyo, Japan) was used to count the number of oral bacteria on the tongue surface, in accordance with the manufacturer's instructions.

\subsection{Oral Sample Processing and DNA Extraction}

An Orcellex ${ }^{\circledR}$ Brush (Rovers Medical Devices, NL, Netherlands) was used to collect samples from the tongue surface, in accordance with the method used in a prior study [8]. The tongue surface was swabbed softly 10 times, using an Orcellex ${ }^{\circledR}$ Brush. Then, the brush was placed in a $1.5 \mathrm{~mL}$ tube containing lysis buffer (Invitrogen, Carlsbad, CA, USA). After removal of the brush, samples were centrifuged at $3000 \times g$ for $10 \mathrm{~min}$; the supernatant was then decanted. DNA was extracted and purified using a PureLink ${ }^{\mathrm{TM}}$ Microbiome DNA Purification Kit (Invitrogen), in accordance with the manufacturer's protocol. This kit enables purification of high-quality microbial DNA from a wide variety of sample types.

\subsection{Detection of Candida Species by PCR}

Each mixture was amplified with $1.0 \mu \mathrm{L}$ DNA, GoTaq ${ }^{\circledR}$ Green Master Mix (Promega, Madison, WI, USA), and primers. We used the following previously described PCR primer sets [9]: Candida albicans, 5'-TTTATCAACTTGTCACACCAGA-3' (sense) and 5'-ATCCCGCCTTACCACTACCG-3' (antisense); Candida glabrata, 5' -TTATCACACGACTCGACACT-3' 
(sense) and 5'-CCCACATACTGATATGGCCTACAA-3' (antisense); and Candida tropicalis, 5'-CAATCCTACCGCCAGAGGTTAT-3' (sense) and 5' -TGGCCACTAGCAAAATAAGCGT-3' (antisense). The PCR program consisted of initial melting at $95{ }^{\circ} \mathrm{C}$ for $5 \mathrm{~min}$, followed by 35 cycles of $95^{\circ} \mathrm{C}$ for $1 \mathrm{~min}, 58^{\circ} \mathrm{C}$ for $1 \mathrm{~min}$, and $72{ }^{\circ} \mathrm{C}$ for $1 \mathrm{~min}$. After the reaction, $10 \mu \mathrm{L}$ of PCR product was electrophoresed on a $2 \%$ agarose gel and stained with ethidium bromide. The universal 16S rRNA gene was used as control; its primer sequences were 5'-CGTTAGTAATCGTGGATCAGAATG-3' (sense) and 5'-TGTGACGGGCGGTGTGTA-3' (antisense).

\subsection{Statistical Analysis}

SPSS Statistics, version 24.0 (IBM Corp., Armonk, NY, USA) was used for statistical analysis. The $\chi^{2}$ test or Fisher's exact test were used to examine significant differences between participant groups, with respect to clinical factors. Student's $t$-test or the Mann-Whitney $U$ test were used to evaluate significant differences in age, remaining teeth, degree of oral moisture, and number of oral bacteria between the two groups. Spearman's rank correlation coefficient was used to examine the correlation between the degree of oral moisture and number of oral bacteria. $p$-values $<0.05$ were considered statistically significant.

\section{Results}

\subsection{Clinical Characteristics of Independent and Dependent Older People}

Table 1 summarizes the clinical characteristics of independent and dependent older people included in this study. There were no significant differences in mean age, sex, body mass index, or medical histories between the groups. In terms of oral health status, the number of remaining teeth was significantly lower in dependent older people than in independent older people. In addition, the proportion of denture users was significantly higher among dependent older people than among independent older people. Importantly, the degree of oral moisture was significantly lower in dependent older people than in independent older people. Furthermore, the number of oral bacteria tended to be higher in dependent older people than in independent older people, but this difference was not statistically significant. To investigate the relationship between the number of oral bacteria and the degree of oral moisture, we examined the correlation between the number of bacteria and level of moisture on the tongue dorsum in the participants. We found a weak negative relationship between the number of bacteria and the level of moisture (Spearman's rank correlation coefficient; $R=-0.29$, $p=0.01)$.

Table 1. Clinical characteristics of independent and dependent older people.

\begin{tabular}{cccc}
\hline Clinical Factor $(\boldsymbol{n})$ & Independent Older People (27) & Dependent Older People (31) & $p$-Value \\
\hline Age (mean) & $82.8 \pm 5.3$ & $85.1 \pm 5.7$ & 0.13 \\
\hline Sex & & & 0.77 \\
Male (15) & $6(22.2 \%)$ & $9(29.0 \%)$ & 0.78 \\
Female (43) & $21(77.8 \%)$ & $22(71.0 \%)$ & 0.39 \\
\hline Body mass index & $22.6 \pm 2.8$ & $22.3 \pm 4.2$ & \\
\hline Hypertension & & & 0.40 \\
No (42) & $18(66.7 \%)$ & $7(77.4 \%)$ & \\
Yes (16) & $9(33.3 \%)$ & & \\
\hline Diabetes & & $29(93.5 \%)$ & $2(6.5 \%)$ \\
No (52) & $23(85.2 \%)$ & $4(14.8 \%)$ & \\
Yes (6) &
\end{tabular}


Table 1. Cont.

\begin{tabular}{|c|c|c|c|}
\hline Clinical Factor $(n)$ & Independent Older People (27) & Dependent Older People (31) & $p$-Value \\
\hline \multicolumn{4}{|l|}{ Hyperlipidemia } \\
\hline No (50) & $22(81.5 \%)$ & $28(90.3 \%)$ & 0.45 \\
\hline Yes (8) & $5(18.5 \%)$ & $3(9.7 \%)$ & \\
\hline \multicolumn{4}{|l|}{ Stroke } \\
\hline No (54) & $25(92.6 \%)$ & $29(93.5 \%)$ & 1.0 \\
\hline Yes (4) & $2(7.4 \%)$ & $2(6.5 \%)$ & \\
\hline \multicolumn{4}{|l|}{ Heart disease } \\
\hline No $(50)$ & $22(81.5 \%)$ & $28(90.3 \%)$ & 0.45 \\
\hline Yes (8) & $5(18.5 \%)$ & $3(9.7 \%)$ & \\
\hline \multicolumn{4}{|l|}{ Dementia } \\
\hline No (53) & $27(100.0 \%)$ & $26(83.9 \%)$ & 0.06 \\
\hline Yes (5) & $0(0.0 \%)$ & $5(16.1 \%)$ & \\
\hline Remaining teeth (mean) & $20.2 \pm 6.3$ & $9.1 \pm 10.2$ & $<0.001$ \\
\hline \multicolumn{4}{|l|}{ Denture user } \\
\hline Non-user (22) & $16(59.3 \%)$ & $6(19.4 \%)$ & 0.003 \\
\hline User (36) & $11(40.7 \%)$ & $25(80.6 \%)$ & \\
\hline Degree of oral moisture & $28.7 \pm 1.7$ & $26.6 \pm 2.9$ & 0.003 \\
\hline $\begin{array}{l}\text { Number of oral bacteria } \\
\left(1.0 \times 10^{6}[\mathrm{CFU}] / \mathrm{mL}\right)\end{array}$ & $9.4 \pm 10.2$ & $13.2 \pm 12.3$ & 0.26 \\
\hline
\end{tabular}

$p$-values $<0.05$ were considered statistically significant.

\subsection{Rates of Oral Candida Detection in Dependent and Independent Older People}

Table 2 summarizes the rates of oral Candida detection in independent and dependent older people in this study. Of the 58 participants, C. albicans was detected in $14(24.1 \%)$, C. glabrata was detected in $13(22.4 \%)$, and C. tropicalis was detected in one (1.7\%). Next, we compared the rates of Candida species detection between independent and dependent older people. Dependent older people exhibited significantly higher rates of C. albicans detection (35.5\%), compared with independent older people (11.1\%). Dependent older people tended to exhibit higher rates of detection of both C. glabrata and C. tropicalis (32.3\% and 3.2\%, respectively), compared with independent older people $(11.1 \%$ and $0.0 \%$, respectively); however, these differences were not statistically significant. In addition, both C. albicans and C. glabrata were detected concurrently in eight participants (including both independent and dependent older people). Dependent older people tended to exhibit a higher rate of concurrent detection of both C. albicans and C. glabrata (32.3\%), compared with independent older people $(11.1 \%)$; however, this difference was not statistically significant. Furthermore, both C. glabrata and C. tropicalis were detected concurrently in one dependent older person.

Table 2. Rates of oral Candida in independent and dependent older people.

\begin{tabular}{cccc}
\hline Clinical Factor $(\boldsymbol{n})$ & Independent Older People (27) & Dependent Older People (31) & $\boldsymbol{p}$-Value \\
\hline C. albicans & $24(88.9 \%)$ & $20(64.5 \%)$ & 0.04 \\
Negative (44) & $3(11.1 \%)$ & $11(35.5 \%)$ & \\
Positive (14) & $24(88.9 \%)$ & $21(67.7 \%)$ & 0.07 \\
\hline C. glabrata & $3(11.1 \%)$ & $10(32.3 \%)$ & 1.0 \\
Negative (45) & & $30(96.8 \%)$ & \\
Positive (13) & $27(100.0 \%)$ & $1(3.2 \%)$ & \\
\hline C. tropicalis & $0(0.0 \%)$ & & \\
Negative (57) & & & \\
Positive (1) & & & \\
\hline
\end{tabular}


Table 2. Cont.

\begin{tabular}{cccc}
\hline Clinical Factor $(\boldsymbol{n})$ & Independent Older People (27) & Dependent Older People (31) & $p$-Value \\
\hline C. albicans/C. glabrata & $25(92.6 \%)$ & $25(80.6 \%)$ & 0.26 \\
Negative (50) & $2(7.4 \%)$ & $6(19.4 \%)$ & \\
Positive (8) & $27(100.0 \%)$ & $30(96.8 \%)$ & 1.0 \\
\hline C. glabrata/C. tropicalis & $0(0.0 \%)$ & $1(3.2 \%)$ & \\
Negative (57) & $p$-values $<0.05$ were considered statistically significant.
\end{tabular}

$p$-values $<0.05$ were considered statistically significant.

\subsection{Clinical Characteristics of Older People Who Required Long-Term Support or Nursing Care}

Table 3 summarizes the clinical characteristics of dependent older people who required long-term support or nursing care. A comparison of clinical characteristics between older people who required long-term support and older people who require nursing care revealed no significant differences in any clinical characteristics.

Table 3. Clinical characteristics of older people who required long-term support or nursing care.

\begin{tabular}{|c|c|c|c|}
\hline Clinical Factor $(n)$ & People Requiring Support (9) & People Requiring Nursing Care (22) & $p$-Value \\
\hline Age (mean) & $86.3 \pm 4.5$ & $84.6 \pm 6.2$ & 0.59 \\
\hline \multicolumn{4}{|l|}{ Sex } \\
\hline Male (9) & $3(33.3 \%)$ & $6(27.3 \%)$ & \multirow[t]{2}{*}{1.00} \\
\hline Female (22) & $6(66.7 \%)$ & $16(72.7 \%)$ & \\
\hline Body mass index & $21.8 \pm 3.8$ & $22.5 \pm 4.5$ & 0.54 \\
\hline \multicolumn{4}{|l|}{ Hypertension } \\
\hline No (24) & $7(77.8 \%)$ & $17(77.3 \%)$ & \multirow[t]{2}{*}{1.0} \\
\hline Yes (7) & $2(22.2 \%)$ & $5(22.7 \%)$ & \\
\hline \multicolumn{4}{|l|}{ Diabetes } \\
\hline No (29) & $8(88.9 \%)$ & $21(95.5 \%)$ & \multirow[t]{2}{*}{0.50} \\
\hline Yes (2) & $1(11.1 \%)$ & $1(4.5 \%)$ & \\
\hline \multicolumn{4}{|l|}{ Hyperlipidemia } \\
\hline No $(28)$ & $8(88.9 \%)$ & $20(90.9 \%)$ & \multirow[t]{2}{*}{1.0} \\
\hline Yes (3) & $1(11.1 \%)$ & $2(9.1 \%)$ & \\
\hline \multicolumn{4}{|l|}{ Stroke } \\
\hline No (29) & $9(100.0 \%)$ & $20(90.9 \%)$ & \multirow[t]{2}{*}{1.0} \\
\hline Yes (2) & $0(0.0 \%)$ & $2(9.1 \%)$ & \\
\hline \multicolumn{4}{|l|}{ Heart disease } \\
\hline No (28) & $7(77.8 \%)$ & $21(95.5 \%)$ & \multirow[t]{2}{*}{0.20} \\
\hline Yes (3) & $2(22.2 \%)$ & $1(4.5 \%)$ & \\
\hline \multicolumn{4}{|l|}{ Dementia } \\
\hline No (26) & $9(100.0 \%)$ & $17(77.3 \%)$ & \multirow[t]{2}{*}{0.29} \\
\hline Yes (5) & $0(0.0 \%)$ & $5(22.7 \%)$ & \\
\hline Remaining teeth (mean) & $15.9 \pm 0.02$ & $16.1 \pm 0.02$ & 0.92 \\
\hline \multicolumn{4}{|l|}{ Denture user } \\
\hline Non-user (6) & $2(22.2 \%)$ & $4(18.2 \%)$ & \multirow[t]{2}{*}{1.0} \\
\hline User (25) & $7(77.8 \%)$ & $18(81.8 \%)$ & \\
\hline Degree of oral moisture & $25.1 \pm 3.5$ & $27.3 \pm 2.4$ & 0.14 \\
\hline $\begin{array}{c}\text { Number of oral bacteria } \\
\left(1.0 \times 10^{6}[\mathrm{CFU}] / \mathrm{mL}\right)\end{array}$ & $12.8 \pm 7.8$ & $13.4 \pm 13.9$ & 0.54 \\
\hline
\end{tabular}

$p$-values $<0.05$ were considered statistically significant. 


\subsection{Rates of Oral Candida Detection in Older People Who Required Long-Term Support or Nursing Care}

Table 4 summarizes the rates of oral Candida detection in dependent older people who required long-term support or nursing care. A comparison of the rates of oral Candida detection between older people who required long-term support and older people who required nursing care revealed that people who required nursing care tended to have higher rates of detection of C. albicans, C. glabrata, and C. tropicalis $(36.4 \%, 36.4 \%$, and $4.5 \%$, respectively), compared with people who required long-term support $(33.3 \%, 22.2 \%$, and $0.0 \%$, respectively); however, these differences were not statistically significant. In addition, both C. albicans and C. glabrata were detected concurrently in seven participants (including both people who required long-term support and people who required nursing care). People who required nursing care tended to exhibit a higher rate of concurrent detection of both C. albicans and C. glabrata $(27.3 \%)$, compared with people who required long-term support (11.1\%); however, this difference was not statistically significant. Furthermore, both C. glabrata and C. tropicalis were detected concurrently in one person who required nursing care.

Table 4. Rates of oral Candida in older people who required long-term support or nursing care.

\begin{tabular}{|c|c|c|c|}
\hline Clinical Factor $(n)$ & People Requiring Support (9) & People Requiring Nursing Care (22) & $p$-Value \\
\hline \multicolumn{4}{|l|}{ C. albicans } \\
\hline Negative (20) & $6(66.7 \%)$ & $14(63.6 \%)$ & 1.0 \\
\hline Positive (11) & $3(33.3 \%)$ & $8(36.4 \%)$ & \\
\hline \multicolumn{4}{|l|}{ C. glabrata } \\
\hline Negative (21) & $7(77.8 \%)$ & $14(63.6 \%)$ & 0.68 \\
\hline Positive (10) & $2(22.2 \%)$ & $8(36.4 \%)$ & \\
\hline \multicolumn{4}{|l|}{ C. tropicalis } \\
\hline Negative (30) & $9(100.0 \%)$ & $21(95.5 \%)$ & 1.0 \\
\hline Positive (1) & $0(0.0 \%)$ & $1(4.5 \%)$ & \\
\hline \multicolumn{4}{|l|}{ C. albicans/C. glabrata } \\
\hline Negative (24) & $8(88.9 \%)$ & $16(72.7 \%)$ & 0.64 \\
\hline Positive (7) & $1(11.1 \%)$ & $6(27.3 \%)$ & \\
\hline \multicolumn{4}{|l|}{ C. glabrata/C. tropicalis } \\
\hline Negative (30) & $9(100.0 \%)$ & $21(95.5 \%)$ & 1.0 \\
\hline Positive (1) & $0(0.0 \%)$ & $1(4.5 \%)$ & \\
\hline
\end{tabular}

$p$-values $<0.05$ were considered statistically significant.

\subsection{Correlations Between Oral Candida Detection and Clinical Features}

To investigate the association between oral Candida detection and clinical factors (excluding dependency status) among older people, we compared clinical characteristics between participants in whom C. albicans was and was not detected (i.e., C. albicans-positive and C. albicans-negative participants) (Table 5). We found no significant differences in mean age, sex, body mass index, or medical histories between the groups. In terms of oral health status, the proportion of denture users tended to be higher among C. albicans-positive participants (71.4\%) than among C. albicans-negative participants $(59.1 \%)$, but this difference was not statistically significant. Furthermore, there were no significant differences in mean age, sex, body mass index, or medical histories between C. glabrata-positive and C. glabrata-negative participants (Table 6). The number of remaining teeth was significantly lower in C. glabrata-positive participants than in C. glabrata-negative participants. The proportion of denture users tended to be higher among C. albicans-positive participants $(84.6 \%)$ than among C. glabrata-negative participants $(55.6 \%)$, but this difference was not statistically significant. 
Table 5. Correlation between C. albicans detection and clinical factors among independent and dependent older people.

\begin{tabular}{|c|c|c|c|}
\hline \multirow{2}{*}{ Clinical Factor $(n)$} & \multicolumn{2}{|c|}{ C. albicans } & \multirow{2}{*}{$p$-Value } \\
\hline & $(-)(n=44)$ & $(+)(n=14)$ & \\
\hline Age (mean) & $83.6 \pm 5.8$ & $85.4 \pm 4.9$ & 0.28 \\
\hline \multicolumn{4}{|l|}{ Sex } \\
\hline Male (15) & $11(25.0 \%)$ & $4(28.6 \%)$ & 0.77 \\
\hline Female (43) & $33(75.0 \%)$ & $10(71.4 \%)$ & \\
\hline Body mass index & $22.3 \pm 3.6$ & $23.0 \pm 4.2$ & 0.29 \\
\hline \multicolumn{4}{|l|}{ Hypertension } \\
\hline No (42) & $29(65.9 \%)$ & $13(92.9 \%)$ & 0.09 \\
\hline Yes (16) & $15(34.1 \%)$ & $1(7.1 \%)$ & \\
\hline \multicolumn{4}{|l|}{ Diabetes } \\
\hline No (52) & $40(90.9 \%)$ & $12(85.7 \%)$ & 0.62 \\
\hline Yes (6) & $4(9.1 \%)$ & $2(14.3 \%)$ & \\
\hline \multicolumn{4}{|l|}{ Hyperlipidemia } \\
\hline No (50) & $38(86.4 \%)$ & $12(85.7 \%)$ & 1.0 \\
\hline Yes (8) & $6(13.6 \%)$ & $2(14.3 \%)$ & \\
\hline \multicolumn{4}{|l|}{ Stroke } \\
\hline No (54) & $40(90.9 \%)$ & $14(100 \%)$ & 0.56 \\
\hline Yes (4) & $4(9.1 \%)$ & $0(0 \%)$ & \\
\hline \multicolumn{4}{|l|}{ Heart disease } \\
\hline No (50) & $38(86.4 \%)$ & $12(85.7 \%)$ & 1.0 \\
\hline Yes (8) & $6(13.6 \%)$ & $2(14.3 \%)$ & \\
\hline \multicolumn{4}{|l|}{ Dementia } \\
\hline No (53) & $40(90.9 \%)$ & $13(92.9 \%)$ & 1.0 \\
\hline Yes (5) & $4(9.1 \%)$ & $1(7.1 \%)$ & \\
\hline Remaining teeth (mean) & $15.0 \pm 10.0$ & $12.0 \pm 10.7$ & 0.36 \\
\hline \multicolumn{4}{|l|}{ Denture user } \\
\hline Non-user (22) & $18(40.9 \%)$ & $4(28.6 \%)$ & 0.53 \\
\hline User (36) & $26(59.1 \%)$ & $10(71.4 \%)$ & \\
\hline Degree of oral moisture & $27.8 \pm 2.5$ & $26.9 \pm 2.9$ & 0.26 \\
\hline $\begin{array}{c}\text { Number of oral bacteria } \\
\left(1.0 \times 10^{6}[\mathrm{CFU}] / \mathrm{mL}\right)\end{array}$ & $10.5 \pm 10.8$ & $14.3 \pm 13.4$ & 0.35 \\
\hline
\end{tabular}

Table 6. Correlation between C. glabrata detection and clinical factors among independent and dependent older people.

\begin{tabular}{|c|c|c|c|}
\hline \multirow{2}{*}{ Clinical Factor $(n)$} & \multicolumn{2}{|c|}{ C. glabrata } & \multirow{2}{*}{$p$-Value } \\
\hline & $(-)(n=45)$ & $(+)(n=13)$ & \\
\hline Age (mean) & $83.6 \pm 6.0$ & $85.5 \pm 3.4$ & 0.29 \\
\hline \multicolumn{4}{|l|}{ Sex } \\
\hline Male (15) & $12(26.7 \%)$ & $3(23.1 \%)$ & 1.0 \\
\hline Female (43) & $33(73.3 \%)$ & $10(76.9 \%)$ & \\
\hline Body mass index & $22.3 \pm 3.6$ & $23.0 \pm 4.2$ & 0.53 \\
\hline \multicolumn{4}{|l|}{ Hypertension } \\
\hline No (42) & $30(66.7 \%)$ & $12(92.3 \%)$ & 0.09 \\
\hline Yes (16) & $15(33.3 \%)$ & $1(7.7 \%)$ & \\
\hline
\end{tabular}


Table 6. Cont.

\begin{tabular}{|c|c|c|c|}
\hline \multirow{2}{*}{ Clinical Factor $(n)$} & \multicolumn{2}{|c|}{ C. glabrata } & \multirow{2}{*}{$p$-Value } \\
\hline & $(-)(n=45)$ & $(+)(n=13)$ & \\
\hline \multicolumn{4}{|l|}{ Diabetes } \\
\hline No (52) & $40(88.9 \%)$ & $12(92.3 \%)$ & 1.0 \\
\hline Yes (6) & $5(11.1 \%)$ & $1(7.7 \%)$ & \\
\hline \multicolumn{4}{|l|}{ Hyperlipidemia } \\
\hline No $(50)$ & $38(84.4 \%)$ & $12(92.3 \%)$ & 0.67 \\
\hline Yes (8) & $7(15.6 \%)$ & $1(7.7 \%)$ & \\
\hline \multicolumn{4}{|l|}{ Stroke } \\
\hline No (54) & 41 (91.1\%) & $13(100 \%)$ & 0.57 \\
\hline Yes (4) & $4(8.9 \%)$ & $0(0 \%)$ & \\
\hline \multicolumn{4}{|l|}{ Heart disease } \\
\hline No (50) & $40(88.9 \%)$ & $10(76.9 \%)$ & 0.36 \\
\hline Yes (8) & $5(11.1 \%)$ & $3(23.1 \%)$ & \\
\hline \multicolumn{4}{|l|}{ Dementia } \\
\hline No (53) & $42(93.3 \%)$ & $11(84.6 \%)$ & 0.31 \\
\hline Yes (5) & $3(6.7 \%)$ & $2(15.4 \%)$ & \\
\hline Remaining teeth (mean) & $16.5 \pm 9.6$ & $6.7 \pm 8.0$ & 0.01 \\
\hline \multicolumn{4}{|l|}{ Denture user } \\
\hline Non-user (22) & $20(44.4 \%)$ & $2(15.4 \%)$ & 0.10 \\
\hline User (36) & $25(55.6 \%)$ & $11(84.6 \%)$ & \\
\hline Degree of oral moisture & $27.7 \pm 2.7$ & $27.3 \pm 2.1$ & 0.63 \\
\hline $\begin{array}{l}\text { Number of oral bacteria } \\
\left(1.0 \times 10^{6}[\mathrm{CFU}] / \mathrm{mL}\right)\end{array}$ & $10.6 \pm 11.4$ & $14.2 \pm 11.7$ & 0.24 \\
\hline
\end{tabular}

$p$-values $<0.05$ were considered statistically significant.

\section{Discussion}

In this study, dependent older people exhibited a significantly higher rate of detection of C. albicans, compared with independent older people. Thiyahuddin et al. have reported that older people living in aged care facilities showed increased rates of detection of both C. albicans and C. glabrata in the oral cavity, compared with similarly aged people living at home [10]. Therefore, dependent older people are more likely to experience oral candidiasis, compared with independent older people. In the present study, dependent older people more commonly wore dentures, compared with independent older people. The fitting surface of denture resin acts as a reservoir for microorganisms (i.e., Candida species) [11]. Thus, poor denture hygiene and prolonged denture use increase the risk of oral candidiasis. Denture use may be associated with high prevalence of oral Candida detection in dependent older people.

Histological changes in the salivary gland due to aging (i.e., decrease in number of acinar cells and increase in amount of fibrous tissue) lead to reductions in salivary flow [12]. This reduced salivary secretion attenuates immunologic and non-immunologic defenses in the oral cavity [12]. In the present study, we examined the degrees of oral moisture in dependent and independent older people of similar age. Dependent older people exhibited significantly lower levels of oral moisture, compared with independent older people. Thus, the salivary secretion capacity may be reduced in many dependent older people. Importantly, we found a significant negative correlation between the degree of oral moisture and the number of oral bacteria in older people. Sue et al. have also described a correlation between the level of moisture and the number of bacteria on the tongue surface in middle-aged and older people [8]. Therefore, we speculate that dry mouth due to aging leads to an elevated number of oral bacteria. Dependent older people are likely to exhibit an increased risk of oral candidiasis because of reduced saliva secretion and poor oral hygiene. 
C. albicans is the predominant pathogenic yeast among Candida species [13]. Biofilm formation by $C$. albicans is involved in its resistance to conventional antifungal drugs [13]. The rate of oral C. glabrata infections has been increasing recently, and these infections have shown potent resistance to azole antifungal agents [14,15]. In addition, mixed infection by C. albicans and C. glabrata has been commonly observed in the oral cavity $[16,17]$. Both C. albicans and C. glabrata were frequently detected concurrently in dependent older people in the present study. Moreover, both C. albicans and C. glabrata were detected concurrently more frequently in people who required nursing care than in people who required long-term support. Both C. glabrata and C. tropicalis were detected concurrently in people who required nursing care alone. These results suggest that older people who experienced decline in activities of daily living are more susceptible to mixed oral Candida infection. Furthermore, mixed infection by C. albicans and C. glabrata has been shown to induce invasion of epithelium by C. glabrata [18]. Mixed Candida infection may contribute to persistent Candida infection in oral mucosa, which results in chronic oral candidiasis in older people. However, the exact mechanism by which C. albicans induces invasion of the epithelium by C. glabrata remains unclear.

We did not investigate the periodontal health of the older people in this study. Importantly, periodontal disease has been associated with systemic disease (e.g., diabetes, cardiovascular disease, and metabolic syndrome) $[19,20]$. In addition, several studies have shown that periodontitis is involved in poor oral health-related quality of life [21-23]. Periodontitis and tooth loss may be associated with changes in cognitive function among older adults [21]. Therefore, prevention and treatment of periodontal disease are necessary to maintain good quality of life among older people.

A previous systematic review demonstrated that patients with dementia had significantly fewer teeth and worse oral hygiene, compared with people who did not have dementia [24]. We were unable to determine the oral hygiene statuses of participants in this study. Therefore, it is unclear whether cognitive function influenced their oral hygiene status. Additional studies are needed to clarify the relationship between cognitive function and oral hygiene in older people.

\section{Conclusions}

Despite the small number of participants in this study, the results indicated that dependent older people may be more susceptible to oral C. albicans infection, compared with independent older people. Mixed infection by C. albicans and C. glabrata may commonly occur in dependent older people. Further research is necessary to confirm whether significant correlations are present between oral Candida infection and oral moisture, as well as between oral Candida infection and denture use, in older people.

Author Contributions: M.M. performed experiments, analyzed and interpreted the data. H.S. designed the study, performed experiments, analyzed and interpreted the data, and wrote the paper. C.-Y.S. and R.N. performed experiments. K.O. discussed and interpreted the data. M.S. designed the study, discussed and interpreted the data and aided in writing the paper. All authors have read and agreed to the published version of the manuscript.

Funding: This study was financially supported by university grants from Hiroshima University.

Conflicts of Interest: The authors declare no conflict of interest.

Data Availability: Data relevant to this study are included in the article.

\section{References}

1. Isola, G.; Polizzi, A.; Muraglie, S.; Leonardi, R.; Lo Giudice, A. Assessment of Vitamin C and Antioxidant Profiles in Saliva and Serum in Patients with Periodontitis and Ischemic Heart Disease. Nutrients 2019, 11, 2956. [CrossRef]

2. Isola, G.; Matarese, G.; Ramaglia, L.; Pedullà, E.; Rapisarda, E.; Iorio-Siciliano, V. Association between periodontitis and glycosylated haemoglobin before diabetes onset: A cross-sectional study. Clin. Oral Investig. 2019. [CrossRef]

3. Terpenning, M. Geriatric oral health and pneumonia risk. Clin. Infect. Dis. 2005, 40, 1807-1810. [CrossRef] [PubMed] 
4. Muzurovic, S.; Babajic, E.; Masic, T.; Smajic, R.; Selmanagic, A. The relationship between oral hygiene and oral colonisation with Candida species. Med. Arch. 2012, 66, 415-417. [CrossRef] [PubMed]

5. Thomas, J.E.; Lloyd, P.M. Oral candidiasis in the elderly. Spec. Care Dent. 1985, 5, 222-225. [CrossRef]

6. Lynge Pedersen, A.M.; Nauntofte, B.; Smidt, D.; Torpet, L.A. Oral mucosal lesions in older people: Relation to salivary secretion, systemic diseases and medications. Oral Dis. 2015, 21, 721-729. [CrossRef] [PubMed]

7. Takahashi, F.; Koji, T.; Morita, O. Oral dryness examinations: Use of an oral moisture checking device and the usefulness of an oral moisture checking device and a modified cotton method. Prosthodont. Res. Pract. 2006, 5, 26-30. [CrossRef]

8. Su, C.Y.; Shigeishi, H.; Nishimura, R.; Ohta, K.; Sugiyama, M. Detection of oral bacteria on the tongue dorsum using PCR amplification of $16 \mathrm{~S}$ ribosomal RNA and its association with systemic disease in middle-aged and elderly patients. Biomed. Rep. 2019, 10, 70-76. [CrossRef]

9. Hsu, M.C.; Chen, K.W.; Lo, H.J.; Chen, Y.C.; Liao, M.H.; Lin, Y.H.; Li, S.Y. Species identification of medically important fungi by use of real-time LightCycler PCR. J. Med. Microbiol. 2003, 52, 1071-1076. [CrossRef]

10. Thiyahuddin, N.M.; Lamping, E.; Rich, A.M.; Cannon, R.D. Yeast species in the oral cavities of older people: A comparison between people living in their own homes and those in rest homes. J. Fungi 2019, 5, 30. [CrossRef]

11. Budtz-Jørgensen, E. Oral mucosal lesions associated with the wearing of removable dentures. J. Oral Pathol. 1981, 10, 65-80. [CrossRef] [PubMed]

12. Vissink, A.; Spijkervet, F.K.; Van Nieuw Amerongen, A. Aging and saliva: A review of the literature. Spec. Care Dent. 1996, 16, 95-103. [CrossRef] [PubMed]

13. Nobile, C.J.; Johnson, A.D. Candida albicans Biofilms and Human Disease. Annu. Rev. Microbiol. 2015, 69, 71-92. [CrossRef] [PubMed]

14. Rodrigues, C.F.; Silva, S.; Henriques, M. Candida glabrata: A review of its features and resistance. Eur. J. Clin. Microbiol. Infect. Dis. 2014, 33, 673-688. [CrossRef] [PubMed]

15. Kamikawa, Y.; Mori, Y.; Nagayama, T.; Fujisaki, J.; Hirabayashi, D.; Sakamoto, R.; Hamada, T.; Sugihara, K. Frequency of clinically isolated strains of oral Candida species at Kagoshima University Hospital, Japan, and their susceptibility to antifungal drugs in 2006-2007 and 2012-2013. BMC Oral Health 2014, 14, 14. [CrossRef] [PubMed]

16. Coco, B.J.; Bagg, J.; Cross, L.J.; Jose, A.; Cross, J.; Ramage, G. Mixed Candida albicans and Candida glabrata populations associated with the pathogenesis of denture stomatitis. Oral Microbiol. Immunol. 2008, 23, 377-383. [CrossRef] [PubMed]

17. Pathak, A.K.; Sharma, S.; Shrivastva, P. Multi-species biofilm of Candida albicans and non-Candida albicans Candida species on acrylic substrate. J. Appl. Oral Sci. 2012, 20, 70-75. [CrossRef]

18. Silva, S.; Henriques, M.; Hayes, A.; Oliveira, R.; Azeredo, J.; Williams, D.W. Candida glabrata and Candida albicans co-infection of an in vitro oral epithelium. J. Oral Pathol. Med. 2011, 40, 421-427. [CrossRef]

19. Morita, T.; Ogawa, Y.; Takada, K.; Nishinoue, N.; Sasaki, Y.; Motohashi, M.; Maeno, M. Association between periodontal disease and metabolic syndrome. J. Public Health Dent. 2009, 69, 248-253. [CrossRef]

20. Bourgeois, D.; Inquimbert, C.; Ottolenghi, L.; Carrouel, F. Periodontal Pathogens as Risk Factors of Cardiovascular Diseases, Diabetes, Rheumatoid Arthritis, Cancer, and Chronic Obstructive Pulmonary Disease-Is There Cause for Consideration? Microorganisms 2019, 7, 424. [CrossRef]

21. Kato, T.; Abrahamsson, I.; Wide, U.; Hakeberg, M. Periodontal disease among older people and its impact on oral health-related quality of life. Gerodontology 2018, 35, 382-390. [CrossRef] [PubMed]

22. Needleman, I.; McGrath, C.; Floyd, P.; Biddle, A. Impact of oral health on the life quality of periodontal patients. J. Clin. Periodontol. 2004, 31, 454-457. [CrossRef] [PubMed]

23. Jansson, H.; Wahlin, Å.; Johansson, V.; Åkerman, S.; Lundegren, N.; Isberg, P.E.; Norderyd, O. Impact of periodontal disease experience on oral health-related quality of life. J. Periodontol. 2014, 85, 438-445. [CrossRef] [PubMed]

24. Foley, N.C.; Affoo, R.H.; Siqueira, W.L.; Martin, R.E. A Systematic Review Examining the Oral Health Status of Persons with Dementia. JDR Clin. Trans. Res. 2017, 2, 330-342. [CrossRef]

(C) 2020 by the authors. Licensee MDPI, Basel, Switzerland. This article is an open access article distributed under the terms and conditions of the Creative Commons Attribution (CC BY) license (http://creativecommons.org/licenses/by/4.0/). 